\title{
Contextual processing of locative prepositional phrases
}

\author{
Nicolas DENAND \& Monique ROLBERT \\ Laboratoire d'Informatique Fondamentale de Marseille \\ 163, avenue de Luminy - Case 901 \\ F-13288 Marseille Cedex 9 \\ France \\ \{Nicolas.Denand,Monique.Rolbert\}@lif.univ-mrs.fr
}

\begin{abstract}
This paper deals with contextual aspects of locative preposition processing. Firstly, accordingly to a study on the referential behavior of the pronominal adverb "y" in its locative uses, we show that static locative prepositions are functions, not only at the conceptual level (as shown in previous studies), but also from a contextual point of view. Such functions introduce new objects in the discourse context, that have to be taken into account in classical contextual processing tasks, such as reference resolution or question answering. Then, we show how these phenomena can fit into contextual formalisms like DRT and DPL.
\end{abstract}

\section{Introduction}

Most often, in a nominal anaphoric relation, a personal pronoun (like "le"(clitic)/"him") is involved in an anaphoric relationship with a nominal phrase (NP), located in the same sentence as the pronoun or a previous one. The pronoun is therefore related to the discourse individual referred to by the NP:

\section{(1) Un homme est venu ce matin. Paul le connaissait. (A man came this morning. Paul knew him.)}

In this example, the pronoun "le"/ "him" is anaphorically linked to the NP "un homme" /"a man". The pronoun refers to the discourse entity introduced by the NP.

The antecedent NP can be found in different syntactical configurations, without being necessarily related to the case of the pronoun itself. For instance, the personal pronoun "elle" /"it" (subject) can be in anaphoric relation to a NP, itself embedded in a complement (here, locative):

(2) J'ai posé mon portable sur la table parce qu'elle était propre. (I put my laptop on the table because it was clean.)

Similarly, the clitic pronoun "y" in its non- locative uses is anaphorically linked to a NP. These uses were already studied (see, for example, (Ruwet, 1990)).

What about locative uses of the pronominal adverb "y" ? That is, when it is used to replace the locative prepositional complement of a verb (Locative Prepositional Phrase, or LPP), like in:

(3) Cette ville est belle. J'y ai vécu autrefois. (This town is beautiful. I lived there formerly.)

Here again, in a classical way, one can say that "y" /"there" refers to a "place" introduced by a NP preceding the pronoun. We have a problem though, to rebuild the exact locative semantics of the pronominal sentence (here, something like "in this town"). The situation gets even more complicated when the antecedent of the pronoun lies itself in a LPP, like in the following:

(4) J'ai passé mes vacances dans le Gard. J'y ai vécu autrefois. (I spent my holydays in the Gard. I lived there formerly.)

In this paper, we show that the pronominal adverb "y" can be anaphorically linked to a LPP, locative preposition included. This leads us to the fact that some LPPs introduce individuals in the discourse context. We discuss the functional role played by locative prepositions in this process. Finally, we explain how to account for these contextual functions within a discourse representation system such as DRT and DPL and its integration into processing a subset of French.

\footnotetext{
$1 " y "$ is usually considered a pronoun for its non locative uses (Ce vase est cassé. N'y touche pas. (This vase is broken. Don't touch it.)) and an adverb elsewhere (Paul y va.(Paul goes there.)). (Grevisse, 1975) notes certain uses in which the status of " $y$ " is unclear. It is then called "pronominal adverb".
} 


\section{Locative prepositions are contextual functions}

A lot of examples show that "y", as a pronominal adverb, may have a NP as syntactical antecedent:

(5) Je vois la table. Tu y as posé tes clefs. (I see the table. You put your keys there.)

If we replace the pronoun with its referent, we have:

(6) Je vois la table. Tu as posé tes clefs sur la table. (I see the table. You put your keys on the table.)

But, differences appear between this last example and a classical anaphoric relationship: first of all, the preposition "sur" /"on", appearing in the rebuilt LPP in (6) does not come from either the antecedent (since this one is a NP), or the verb ("sur"/"on" is not a mandatory preposition for the verb "poser"/"put", since this one accepts other prepositions like in "poser dans" /"put in" or "poser sous"/"put under"). Moreover, the coreference link between the pronoun and its antecedent (usually generated by the anaphoric relation) is unclear: can we really assume that "y" "there" refers to the object designated by the NP "the table"? A first answer to these problems could be that there is a kind of metaphoric interpretation of the object designated by the antecedent NP, which would allow it to designate also a place, for instance the location where it stands, or its interior when the name of the object clearly suggests an interiority feature. This approach was studied and approved by (Mackenzie, 2004) and similar ideas (though in the conceptual domain) can be found in (Flageul, 1997). Nevertheless, we can notice that it is rare for the pronoun " $y$ " to designate the place defined this way. In example (5), one cannot say that "y" refers to the place occupied by the table. Moreover, such an interpretation of the involved phenomenon does not allow to account for the following examples:

(7) Va chercher près de la table, je crois que ton ballon s'y trouve. (Go look near the table, I think your ball is there.)

(8) Je suis allé derrière la maison. Un vélo s'y trouvait. (I went behind the house. A bicycle was there.)

(9)Quand j'ai posé mon sac à côté de la tasse, ton portable s'y trouvait. (When I put my bag next to the cup, your laptop was there.)
If we replace the pronoun with its antecendent, we have:

(10) Va chercher près de la table, je crois que ton ballon se trouve près de la table. (Go look near the table, I think your ball is near the table.)

(11) Je suis allé derrière la maison. Un vélo se trouvait derrière la maison. (I went behind the house. A bicycle was behind the house.)

(12) Quand j'ai posé mon sac à côté de la tasse, ton portable se trouvait à côté de la tasse. (When I put my bag next to the cup, your laptop was next to the cup.)

The difference between these examples and (5) resides in the fact that, here, the preposition employed in rebuilt examples (10), (11) and (12) is necessarily the same as the preposition involved in the LPP of the previous sentence. We notice that the syntactical similarity between the antecedent LPP and the rebuilt one does not come from a pure syntactic relationship between the pronominal adverb and its antecedent. In addition, there really is a coreference relationship since, in example (10) for instance, both LPPs mention the same table and, in fact, the same 'place'. Therefore, we have to account for the coreference link between pronoun " $y$ " and a 'place', described by the antecedent LPP. We must then consider that " $y$ " is anaphorically related to the LPP and, hence, refers to an 'object' introduced by this LPP and different from that designated by the NP.

Studying where-questions raises a valuable analogy. For instance, let us consider a static locative question like:

(13) Où se trouve mon portable? (Where is my laptop?)

One possible answer to this question, within a universe described by example (9) above, is:

(14) À côté de la tasse.(Next to the cup.)

If we classically consider that the semantics of such questions (wh-questions) is the maximal set of individuals satisfying the property corresponding to the question (on this subject, see (Van Rooy, 1999), (Groenendijk and Stokhof, 1984)), then we must admit that "à côté de la tasse" /"next to the cup" is an individual. As a matter of fact, the semantics of question (13) is: 
$\{x /$ se_trouve (mon_portable, $x)\}^{2}$

and one element of this set is therefore an object that can be designated by the LPP "à côté de la tasse" /"next to the cup" (which is clearly a different object from the one designated by the NP "la tasse" /" the cup").

Thus, we conclude that LPPs introduce individuals that can be viewed as answers to locative questions. Then it appears that these individuals are precisely those that can be designated by adverb " $y$ " in situations similar to the examples given above. Other examples give support to this point of view. The anaphoric use of locative adverb "là"/"there" 3 or repetitions by definite description show us other cases that require to assume the existence of LPPsgenerated individuals:

(15) Je suis en face du cinéma. On se retrouve là. (I am in front of the cinema. Let's meet there.)

(16) Je suis à droite de l'arbre. L'endroit est magnifique. (I am to the right of the tree. The place is beautiful.)

Therefore, we give the following rule:

Some $^{4}$ LPPs introduce/designate two individuals: one classical, given by the contextual interpretation of the embedded NP, the other given by the interpretation of the LPP itself (that is, by the compound [prep + NP]). The pronominal adverb " $y$ " may be anaphorically linked to a LPP (that is, precisely, to the phrase made of $[$ prep $+N P])$, thus referring to the individual introduced by the complete LPP.

Then, what happens when "y" has a NP for an antecedent? The NP is its antecedent but it has no coreference relationship with it. On can think here that we are facing a relationship close to bridging anaphora (like "la porte" /"the door"..."la poignée"/"the handle"). But instead of having a classical part/whole relationship between the two members of the anaphora, we have an underspecified (the preposition is missing) relationship of type object/place. "y"

\footnotetext{
${ }^{2}$ There is no way to introduce the preposition "next to" in this semantic formula from the surface form of the question.

${ }^{3}$ See the work of (Lorentzen, 1998) on the distinct behaviors of "ici" /"here" and "là"/"there".

${ }^{4} \mathrm{We}$ will see later that determining what LPPs are involved in this rule is a difficult question, unanswered in this paper.
}

is therefore involved in a coreference relationship with another object than the one designated by its antecedent. The semantics of this object depends on the antecedent NP and a (yet undetermined) preposition. We notice that even if the antecedent NP is embedded in a LPP, the preposition of the latter is not always referred to by the pronoun. The following example:

(17) Max habite loin du parking mais j'y ai (quand même) garé ma voiture.(Max lives far from the carpark, but I (nevertheless) left my car there.)

can be paraphrased by:

(18) Max habite loin du parking mais j'ai quand même laissé ma voiture dans le parking. (Max lives far from the carpark, but I (nevertheless) left my car in the carpark.)

In these situations, the preposition "far from" is not part of the anaphoric relation. We will say that the syntactic antecedent of the pronoun is the embedded NP (and not the LPP) and we will introduce a new locative preposition to calculate the referent of "y"/"there".

We notice that this process makes the interpretation of pronoun " $y$ " potentially ambiguous when this one refers to a LPP: the pronoun can indeed refer to the LPP or have the NP (embedded in the LPP) as an antecedent. The following example shows such an ambiguity:

(19) J'habite à côté de Paris et j'y travaille.(I live near Paris and I work there.)

There are two possible interpretations for this sentence:

(20) J'habite à côté de Paris et je travaille à côté de Paris. (I live near Paris and I work near Paris.)

(21) J'habite à côté de Paris et je travaille à Paris.(I live near Paris and I work in Paris.)

Finally, we notice that the behavior of relative sentences introduced by "où" /"where" is similar to the examples above, except the fact that the antecedent is always a NP:

(22) Je vois la table où tu as posé ton portable.(I see the table where you put your laptop.)

(23) Max habite loin du parking où j'ai laissé ma voiture. (Max lives far from the carpark where I left my car.)

The antecedent of the relative pronoun "où" /"where" is the NP which is embedded in 
the locative complement and its semantics must be completed by a (implicit) locative preposition (it could be replaced in surface forms by "on which"/"in which").

Now that we showed that some LPPs introduce/designate one discourse individual, we must have a closer look at the underlying phenomenon. Many studies dealt with contextual effects of NPs (definite/indefinite, generic/specific, etc. see, for instance, (Corblin, 1987)). A summary of these can be found in (Salmon-Alt, 2001). Where do LPPs fit in there? First of all, we notice that the situation is complicated since it depends obviously on the nature of the NP which is embedded in the LPP and, for example, some cases of "generic LPPs" can be encountered, like in:

(24)Habiter près d'un crématorium comporte également des risques : la mortalité natale y est plus élevée de 4\%. (It is also risky to live near a crematorium: birth mortality is higher by $4 \%$ there.)

We will firstly focus on LPPs containing two types of NPs: indefinite with specific interpretation and definite descriptions (or any referential expression, for instance pronominal). In both cases we get, after the interpretation of the embedded NP, an entity, either pre-existing the interpretation of the NP or newly created. This entity serves as a basis to determine the new entity generated by the interpretation of the LPP. Clearly, the other tool allowing to determine this new entity is the locative preposition involved in the LPP: what is its status? Several studies on space representation give definitions (either qualitative or quantitative) of the part of space designated by a spatial function applied to an object or a place. These works usually focus on explaining the conditions under which one can say that a point of space (or an object) is or not within such a part of space (see, for example (Vieu, 1991), (Schang, 1997)). This belonging is then most often represented by a spatial relation (like to_be_on_the_right_of) between objects, which will be either true or false.

These processes do not highlight this part of space that we aim to raise as a discourse object, but they show the matching between some locative prepositions and spatial functions ${ }^{5}$. Other

\footnotetext{
${ }^{5}$ Here, again, it seems difficult to state that every locative preposition matches a spatial function. This question will not be discussed in this paper. But, such a study could probably rely on the classification of locative prepositions proposed in (Borillo, 1993) and (Borillo,
}

studies also highlight this role of locative prepositions. V. Flageul (Flageul, 1997) considers locative prepositions as conceptual-level operators, which turn a type object into a type place. A. Peyraube (Peyraube, 2003) describes the historical evolution of Chinese localizers and notes that "their main function in pre-medieval Chinese is to follow nouns and transform them into place words, tending to behave like functional words". We take one step further and state that locative prepositions are contextual-level operators (or "functions", from a logical point of view) which produce an object from another, the former being the part of space cited before. The work of V. Flageul allows us to specify the conceptual type of this object according to the involved preposition.

Concerning LPPs that contain NPs quantified by 'every', the situation slightly differs: typically, such NPs imply universally quantified variables. We will get back on this point when examining examples in the next paragraph.

As a conclusion for the current section, we state that in the situations described above: Some locative prepositions denote contextual functions: they associate to one individual $X$ from the context another one, noted $f(X)$. Some LPPs produce an object $f(X)$ where $f$ is the function associated to the locative preposition and $X$, the object designated or produced by the embedded NP.

\section{Processing preposition functions with DRT and DPL}

We are now going to show how to integrate these functions when representing discourse and referential links. First of all, we show on examples $^{6}$ how this works within DRT-like formalism. Then we show results obtained in a DPL approach.

2000).

${ }^{6}$ The examples we use here are simple on purpose and may therefore seem odd or ill-formed. Nevertheless, we can give many others where "y" refers to a LPP. A brief search on the Internet allowed us to reveal examples of various types:

(25) Nous nous sommes promenés près d'un volcan et nous y avons trouvé des roches intéressantes. (We had a walk near a volcano and we found interesting rocks there.)

(26) Les terrains primitifs, en faisant irruption dans les terrains primordiaux, y ont amené un certain nombre de minéraux intéressants.(Primitive terrains, when rushing into primordial terrains, brought a certain number of interesting minerals there.) 
DRT ((Kamp, 1981)) is a theory proposing a discourse representation formalism, essentially oriented towards (pronominal and others) reference problems. We show here with the cases studied in the previous section how a LPP and a referent to a LPP can be accounted for within this formalism.

(30) Un arbre se trouve derrière une maison. Il y fait de l'ombre. (There is a tree behind a house. It casts shadow there.)

\begin{tabular}{|l|}
\hline$x y z$ \\
\hline tree $x$ \\
house $y$ \\
$z=\operatorname{behind}(y)$ \\
is_located $(x, z)$ \\
\hline
\end{tabular}

Figure 1: DRS of example (30) (step 1)

Comments: indefinite NPs "un arbre"/"a tree" and "une maison" /"a house" classically introduce two new individuals in the Discourse Representation Structure (DRS). The LPP introduces a new individual $z$, being the result of the application of function behind on reference marker $y$.

Example continuation:

(27)Au moment du projet, la densité des moules zébrées,..., était de faible à modérée près de Burritts Rapids, mais elle y augmentait rapidement. (At the time of the project, the density of zebra mussels,..., was low to moderate near Burritts Rapids, but it was quickly increasing there.)

(28)Durant le projet, c'est près de chaque section qu'on a observé les plus bas niveaux de bactéries E. Coli de toute la rivière. Le niveau d'E. Coli y était assez faible pour que la baignade y soit permise presque tous les jours.(During the project, the lowest levels of $E$. Coli bacteria in all the river were observed near every section. The level of E. Coli was low enough there to permit swimming on most days.)

(29)Les gens préfèrent acheter loin du centre ville car ils y trouvent des logements peu chers.(People prefer buying far from downtown because they find cheap residences there.)

\begin{tabular}{|l|}
\hline$x y z v w$ \\
\hline tree $x$ \\
house $y$ \\
$z=\operatorname{behind}(y)$ \\
is_located $(x, z)$ \\
$v=x$ \\
$w=z$ \\
casts_shadow $(v, w)$
\end{tabular}

Figure 2: DRS of example (30) (step 2)

Comments: classically, pronoun "il" /"it" introduces a new reference marker $v$ linked to its antecedent by the equality $v=x$. "y" /"there" also introduces a new reference marker $w$ linked to its antecedent by equality $w=z$. The fact that the antecedent $z$ is itself linked to a functional term is without consequence.

(31) Si un arbre se trouve derrière une maison, il y fait de l'ombre. (If a tree is behind a house, it casts shadow there.)

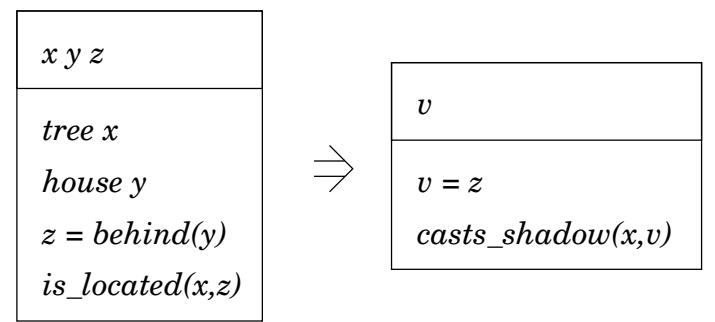

Figure 3: DRS of example (31)

Comments: this example is equivalent to a donkey sentence. Thanks to its location inside the DRS, reference marker $z$ is accessible from variable $v$.

(32) Un arbre se trouve derrière chaque maison et $y$ fait de l'ombre. (A tree is behind everyhouse and casts shadow there.)

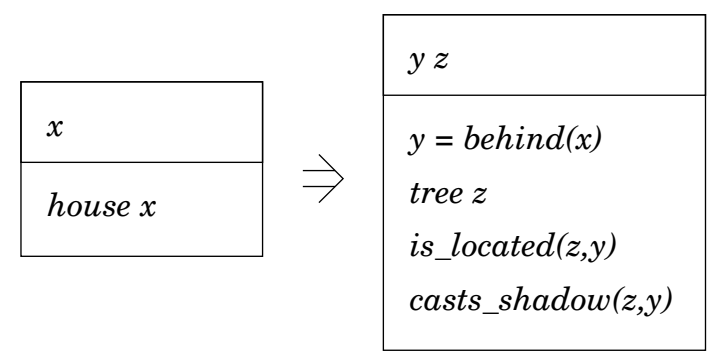

Figure 4: DRS of example (32) 
Comments: we chose here the interpretation in which the quantifier "chaque" /" every" has a scope beyond the indefinite subject. We notice that the quantification associated to variable $y$ is existential (from its presence in the right box of the implication) and not universal, like it would have been the case if variable $y$ was present in the left box. This choice is not really important since the result of a function is, by definition, unique.

Through these examples, we can see that repetitions of functional terms are always done within the scope of the argument quantification: indeed, either both terms are introduced in the same box - at the same level - or the functional term is introduced in the right box of an implication (it is therefore in the scope of the variable introduced in the left box). To remain correct, every reference to this functional term will occur in the same context.

These processes are thus classical. Functional terms just have to be introduced in DRT notation. In the "classical" DRT definition (like it is presented, for instance, in (van Eijck and Kamp, 1997), p. 191), terms are either constants or variables used as reference markers or discourse referents. We added functions in the language. We assume that a set of function letters with their arities is given. Then the set of terms is augmented by functional terms. Practically, these functional terms are obtained by applying functions on variables.

Thus, a locative preposition corresponds to a function from this language. One can see to which typed lambda-expressions lexical items or phrases must be associated to obtain the results given above. According to notations from (van Eijck and Kamp, 1997) p. 217, we can state that a locative preposition is of type $\langle e, e\rangle$ and has as lambda-expression $\lambda v$ (behind $v$ ) if behind is the function associated to the preposition. The LPP causes the new individual to appear in the DRS. It is of type $<<e, T\rangle$ ,$T>$ (like a NP) and its lambda expression is $\lambda P\left(u_{i} ;\left(N P \quad \lambda v\left(u_{i}=\left(L_{L} c_{-} P r e p v\right) . P\left(u_{i}\right)\right)\right)\right)$ where $N P$ denotes the lambda-expression given from the LPP-embedded NP, Loc_Prep is the lambda-expression of locative preposition given above and $u_{i}$ the reference marker introduced by the LPP. Finally, pronoun "y" will be associated to lambda-expression $\lambda P\left(P u_{i}\right)$ where $u_{i}$ is its antecedent reference marker ${ }^{8}$.

\footnotetext{
${ }^{8}$ We can not detail here the lambda-expressions associated to other phrases or items required for complete
}

DPL (Groenendijk and Stokhof, 1984) is another discourse representation system allowing easy expression of referential links. To account for our LPP processing, the language must be augmented with functions and functional terms (which raises a priori no problem). Here are some DPL formulas corresponding to the following examples:

(33) Un arbre se trouve derrière une maison. (A tree is behind a house.)

$\exists x \exists y[\operatorname{tree}(x) \wedge \operatorname{house}(y) \wedge i s(x, \operatorname{behind}(y))]$

(34) Il y fait de l'ombre. (It casts shadow there.) $\exists x \exists y[\operatorname{tree}(x) \wedge \operatorname{house}(y) \wedge i s(x, \operatorname{behind}(y))] \wedge$ casts_shadow $(x$, behind $(y))$

The occurrence of the variable in the functional term is linked by its quantifier, like in case of pronominal repetition without function. The well-formedness of formulas is therefore guaranteed.

(35) Si un arbre se trouve derrière une maison, il y fait de l'ombre. (If a tree is behind a house, it casts shadow there.)

$[\exists x \operatorname{tree}(x) \wedge \exists y[$ house $(y) \wedge i s(x, \operatorname{behind}(y))]] \Rightarrow$ casts_shadow $(x$, behind $(y))$

In order to build these DPL formulas, we associate to locative prepositions the lambda-expression $\lambda v$ (behind $v$ ) of type $<$ $e, e>$, and to LPPs the lambda-expression $\lambda P[N P \lambda y[P[$ Prep_Loc $y]]]$ of type $<<e, T>$ ,$T>$ ([ ] are used as application operator). These expressions are very close to those used in DRT, apart from the fact that they do not introduce reference markers. In the absence of these markers, the link between pronoun "y" and its functional antecedent is established by using the same variable appearing in the antecedent functional term and building a new functional term from the same function. The lambda-expression associated to "y" then becomes $\lambda P[P[$ Prep_Loc $x]]$ where [Prep_loc $x]$ is the antecedent of " $y$ ".

\section{Conclusion}

In this paper, we studied the contextual consequences of the referential interpretation of locative prepositional phrases through references by pronominal adverb " $y$ ". We stated that locative prepositions are functions at a contextual level and that LPPs introduce new individuals into the discourse context.

processing of our examples. The approach is classical and the reader can refer, for instance, to (van Eijck and Kamp, 1997) 
The results described here are used within a platform (made by our team) allowing to develop natural language understanding applications featuring a syntactical analysis phase, a lambda-calculus-based representation of sentences and a contextual processing of discourse (proforms and definite descriptions resolution). We use DRT to resolve references, then DPL for a final discourse representation.

Many difficult questions remain unanswered. First of all, it seems that only some LPPs provide such a productive ability at a contextual level and that it depends on both the locative preposition and the type of the embedded NP. Classifying and characterizing these types of NPs remain to be done. Dynamic LPPs should also be studied. Besides we could study the behavior of other prepositional syntagms (temporal prepositions, for instance).

\section{References}

A. Borillo. 1993. Prépositions de lieu et anaphores. Langages, pages 27-46.

A. Borillo. 2000. Formes et sens des prépositions. In PREP-AN 2000. University of Tel-Aviv.

D. Corblin. 1987. Indéfini, défini et démonstratif. Droz, Genève-Paris.

V. Flageul. 1997. Description sémanticocognitive des prépositions spatiales $d u$ français. Ph.D. thesis, Université Paris IV Sorbonne.

M. Grevisse. 1975. Le bon usage. Duculot.

J. Groenendijk and M. Stokhof. 1984. Studies in the semantics of questions and the pragmatics of answers. Ph.D. thesis, University of Amsterdam.

H. Kamp. 1981. A theory of truth and semantic representation. In J. Groenendijk, T. Jansen, and M. Stokhof, editors, Formal methods in the study of language, Mathematisch Centrum, Amsterdam.

L. R. Lorentzen. 1998. Je serai là ou J'y serai ? - voilà la question. In A. Englebert, M. Pierrard, L. Rosier, and D. van Raemdonck, editors, Actes du XXIIe Congrès International de Linguistique et de Philologie Romanes, Bruxelles.

L. Mackenzie. 2004. Anaphoric reference to entities and places in literal and metaphorical contexts. In J. Andor and P. Pelyvás, editors, Empirical, cognitive-based studies in the semantics-pragmatics interface, Amsterdam. Elsevier. to be published.
A. Peyraube. 2003. On the history of place words and localizers in chinese: a cognitive approach. Space in languages: linguistic systems and cognitive categories, february.

N. Ruwet. 1990. En et y : deux clitiques pronominaux antilogophoriques. Langages, 97. Larousse.

S. Salmon-Alt. 2001. Référence et dialogue finalisé : de la linguistique à un modèle opérationnel. Ph.D. thesis, LORIA, Université Henri Poincaré, Nancy I.

D. Schang. 1997. Représentation et interprétation de connaissances spatiales dans un système de dialogue homme-machine. Ph.D. thesis, Université Henri Poincaré, Nancy I.

J. van Eijck and H. Kamp. 1997. Representing discourse in context. In J. van Benthem and A. ter Meulen, editors, Handbook of Logic and Language. Elsevier.

R. Van Rooy. 1999. Questioning to resolve decision problems. In P. Dekker, editor, Proceedings of the 12th Amsterdam Colloquium, Amsterdam.

L. Vieu. 1991. Sémantique des relations spatiales et inférences spatio-temporelles : une contribution à l'étude des structures formelles de l'espace en Langage Naturel. Ph.D. thesis, IRIT, Université Paul Sabatier. 